\title{
Digital terrain modelling to investigate the effects of sea level rise on mangrove propagule establishment
}

\author{
D. Di Nitto ${ }^{1,2}$, F. Dahdouh-Guebas ${ }^{1,3, *}$, J. G. Kairo ${ }^{4}$, H. Decleir ${ }^{2,5}$, N. Koedam ${ }^{1}$ \\ ${ }^{1}$ Biocomplexity Research Focus c/o Laboratory of Plant Biology and Nature Management, Mangrove Management Group, \\ Vrije Universiteit Brussel, Pleinlaan 2, 1050 Brussels, Belgium \\ ${ }^{2}$ Laboratory of Cartography and Geographic Information Systems, Vrije Universiteit Brussel, Pleinlaan 2, 1050 Brussels, \\ Belgium \\ ${ }^{3}$ Département de Biologie des Organismes, Université Libre de Bruxelles (ULB) — Campus du Solbosch, CP 169, \\ Avenue Franklin D. Roosevelt 50, 1050 Bruxelles, Belgium \\ ${ }^{4}$ Kenya Marine and Fisheries Research Institute, PO Box 81651, Mombasa, Kenya \\ ${ }^{5}$ Laboratory of Physical Geography, Vrije Universiteit Brussel, Pleinlaan 2, 1050 Brussels, Belgium
}

\begin{abstract}
We studied the vegetation structure dynamics of mangroves, in order to contribute to an overall view on the conditions of propagule establishment from the moment they detach from the parental tree. Microtopographical measurements, quantitative data on vegetation, and propagule counts were collected in Gazi Bay (Kenya) and utilized in a 'geographical information systems' (GIS) environment where all modelling took place based on digital terrain modelling (DTM). Suitability maps were created for propagules of Rhizophora mucronata and Ceriops tagal to analyse the dispersal possibilities (through stranding or self-planting) for the present situation, and for cases of degradation and sea level change. The GIS-analyses take into account the available information derived from the field data, but alterations that go hand in hand with degradation and/or sea level changes (e.g. erosion patterns, rates of sediment supply, wave action) were not considered, since our main focus was the behaviour of propagules. We found that the study area has the potential to successfully rejuvenate at present; however, increasing anthropogenic pressure may have severe consequences on propagule dispersal within this mangrove stand, mainly through the loss of aerial root masses, as these were shown to provide stranding areas for propagules. A relatively modest rise in sea level within a time span of 20 yr could affect the distribution pattern and the specific proportion of the juvenile vegetation layer, leading to notable floristic modifications from a regional point of view.
\end{abstract}

KEY WORDS: Mangrove $\cdot$ Propagule dispersal $\cdot$ Topography $\cdot$ GIS $\cdot$ DTM $\cdot$ Roots $\cdot$ Kenya $\cdot$ Gazi Bay

\section{INTRODUCTION}

Mangrove systems are often described as zoned, according to the intertidal environmental gradients evident in their habitat (e.g. Macnae 1968). Along the East African coast, these ecosystems are reported to thrive in an intertidal area featuring a regular slope from the terrestrial areas towards the sea (e.g. Walter \& Steiner 1936). In spite of their usefulness as breeding, spawning, hatching and nursery grounds for a diverse fauna, as a protection against coastal erosion (e.g.
Othman 1994, Dahdouh-Guebas et al. 2005a) and extreme weather events (e.g. Badola \& Hussain 2005) and as a source of wood (Baran 1999, DahdouhGuebas et al. 2000a, Barbier \& Cox 2002, Kairo et al. 2002, Barbier 2003), mangroves are being destroyed and are threatened worldwide. In recent decades the global coverage of mangroves along tropical coastlines has declined from $75 \%$ (Chapman 1976) to ca. $25 \%$, mainly by logging, expansion of agriculture, aquaculture (Farnsworth \& Ellison 1997), irrigation systems (Dahdouh-Guebas et al. 2005b), tourism development 
and oil spills (Duke et al. 1997). Another plausible future environmental change cannot be left unmentioned, i.e. sea level rise, as the Intergovernmental Panel for Climate Change (IPCC) states a conservative scenario of $4.8 \mathrm{~mm} \mathrm{yr}^{-1}$ (IPCC 2001). This could have a major influence on mangrove ecosystems, depending on the actual rate of the sea level rise, the sediment supply and the topography of the coastline (Woodroffe 1990, Gilman et al. 2006).

Relationships between the vegetation structure and abiotic, biotic and human factors have been investigated through both linear and multivariate analyses (Gallin et al. 1989, Matthijs et al. 1999, DahdouhGuebas et al. 2000b, 2002a,b, Dahdouh-Guebas \& Koedam 2002). Although such studies have provided insight into plant-environment relationships in adult individuals, they have contributed little to the understanding of propagule establishment. There is in fact a research gap between the results derived from reproductive phenology, which usually stops with the maturing of propagules on parental trees (e.g. Christensen \& Wium-Andersen 1977, Wium-Andersen \& Christensen 1978, Wium-Andersen 1981, Duke 1990, Ochieng \& Erftemeijer 2002), and the results provided by vegetational and physio-ecological research, which only starts from established young or adult trees and studies the effect of the environment on propagule growth or survival (e.g. McMillan 1971, Palihawadene \& Pinto 1989, McKee 1993, Matthijs et al. 1999, Krauss \& Allen 2003). Our current scientific understanding therefore cannot account for the period between the mature, falling propagule and its establishment.

It has been suggested that mangrove trees of the family of the Rhizophoraceae reach a particular place by one of following strategies: either the planting strategy or the stranding strategy. The planting strategy states that when the torpedo-shaped propagules drop from the adult tree, they can self-plant in the muddy substrate. The stranding strategy however indicates that propagules can be transported through water and thereby strand in areas further afield, either within the same or another mangrove forest, or sometimes even colonising a bare site. Various authors have been inclined to support either the planting (e.g. La Rue \& Muzik 1951) or the stranding strategy (e.g. Egler 1948, Rabinowitz 1978a,b). However, Van Speybroeck (1992) reported that self-planting appears to be the major mechanism of propagule dispersal in relatively undisturbed mangrove forests, while stranding proves to be dominant in colonizing over-exploited and cleared mangrove forests. Our experience with mangroves in Africa and Asia indicates that many mangrove species, in particular Rhizophoraceae representatives, have a well-developed canopy, younger tree layers and a complex root labyrinth, all of which hinder a perfect fall and self-planting in the substrate. We believe that in natural situations the influence of water in propagule dispersal is more important than commonly accepted. Unfortunately, it is seldom highlighted that microtopography in a 3-dimensional (3D) space can strongly influence the water accessibility within a specific region and that investigating this aspect as an influential factor in the dispersion of mangrove propagules could open new vistas within this area of expertise. At best, only the influence of floating debris in propagule establishment has been demonstrated (Delgado et al. 2001, Krauss et al. 2005); the 2Dintertidal position was used as a measure of elevation to interpret zonation patterns (Santos et al. 1997), and land-water ratios were used to quantify stranding ability (Dahdouh-Guebas 2001).

It is known that clear-felling of mangroves in general, and therefore also in our study area Gazi Bay, negatively influences natural regeneration and this is most likely due to the resulting unfavourable site conditions (Bosire et al. 2003). Mangroves do not have a seed bank, but propagules disperse, settle and establish when they encounter a suitable habitat.

Root systems like prop roots and pencil roots can play an important role in trapping these dispersion units and assuring the establishment of a sapling bank (Ellison 2000), while they can also dissipate current energy and in this way trap sediment in their structures (Mazda et al. 1997, Phuoc \& Massel 2006), causing a modification in the grain size distribution of the substrate (Bosire 1999). Primarily, clay and silt are trapped by these systems, while naked sites within mangrove areas are often covered by sandy substrates. Bosire (1999) proved that bare sites can remain in the same state for a substantial time (at least, no colonization was observed for ca. $10 \mathrm{yr}$ ); propagules and juveniles will successively be washed away by incoming and outgoing tides, thus natural regeneration will no longer be possible (Kairo 2001). Clear-felling of these trees and their associated root systems can therefore have severe consequences on propagule dispersal and establishment, and furthermore clear-felling is closely associated with a decreased stability of the soil which enhances erosion and which can therefore cause an alteration in elevation.

The aim of the present paper is to investigate the influence of microtopography - defined as soil height differences between neighbouring trees within a particular mangrove assemblage - and some associated factors (root complexity, type of substrate) on the suitability for the establishment of mangrove propagules of 2 Rhizophoraceae species (Ceriops tagal and Rhizophora mucronata). By (1) constructing a digital terrain model (DTM) of very high spatial resolution, (2) knowing the exact position of individual trees and (3) 
monitoring propagule stranding/self-planting occurrence, it was possible to simulate water level fluctuations and create maps that indicate the suitability for stranding or self-planting of each species concerned. This mangrove study on digital terrain modelling was restricted to zoned mangroves. However, alterations resulting from degradation and/or sea level changes (e.g. changes in topography, geomorphology, coral growth, wave action, siltation through El Niño rains) are beyond the scope of this study. The main focus here was propagule dispersion.

\section{MATERIALS AND METHODS}

Area description. Located at $4^{\circ} 26^{\prime} \mathrm{S}, 39^{\circ} 30^{\prime} \mathrm{E}$, Gazi is a village situated on the southern coast of Kenya approximately $45 \mathrm{~km}$ south of the historic port (Kilindini) of Mombasa (Fig. 1). The mangrove forests along the bay of Gazi cover an area of $5 \mathrm{~km}^{2}$ and are dominated by 10 East African mangrove species: Avicennia marina (Forsk.) Vierh., Bruguiera gymnorrhiza (L.) Lam., Ceriops tagal (Perr.) C. B. Robinson, Heritiera littoralis Dryand., Lumnitzera racemosa Willd., Rhizophora mucronata Lam., Sonneratia alba Sm., Xylocarpus granatum Koen, $X$. moluccensis (Lamk.) Roem, and Pemphis acidula Forst. (nomenclature according to Tom- linson 1986). Gazi Bay has recurrently been described as a bay fringed with mangrove forests, seagrass beds and coral reefs (Gallin et al. 1989, Coppejans et al. 1992, Hemminga et al. 1994, Slim et al. 1996, DahdouhGuebas et al. 2002a,b).

The topographical measurements were conducted at an area of ca. 0.1 ha within a mixed mangrove stand dominated by Rhizophora mucronata and Ceriops tagal, whilst the propagule counts were conducted along 5 line transects throughout the forest (Fig. 1). The fieldwork was done over a time span of $6 \mathrm{wk}$ in February-March 2002, the hot dry season of Kenya. The dry seasons coincide with the Indian Ocean monsoon currents: warm during the Northern Hemisphere northeast monsoon and cool during the Southern Hemisphere southeast monsoon, reflecting the different origins of the air masses and their fetch over ocean or desert (Glantz 1998).

Microtopographical field survey and construction of a DTM. The final aim of the microtopographical field survey was to construct a DTM, the electronic process of representing topography in 3 dimensions.

Surveying methods: Using an optical level and a $4 \mathrm{~m}$ aluminium tower ruler divided into $0.5 \mathrm{~cm}$ intervals, an area of $840 \mathrm{~m}^{2}$ (Fig. 1) was covered to measure the elevation of the mangrove soil with a final resolution of $25 \times 25 \mathrm{~cm}$ in the topographical rough areas and a
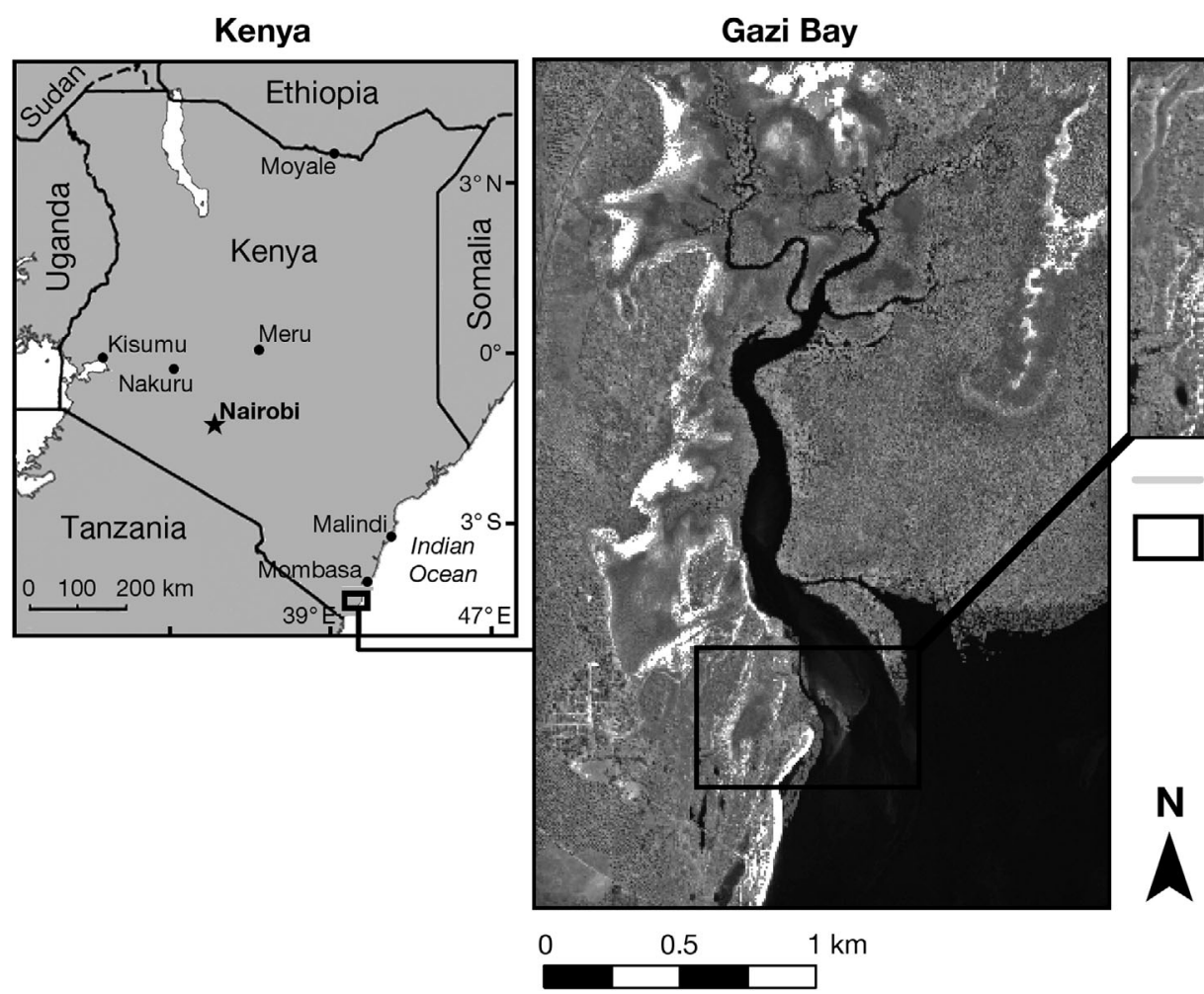

Study site

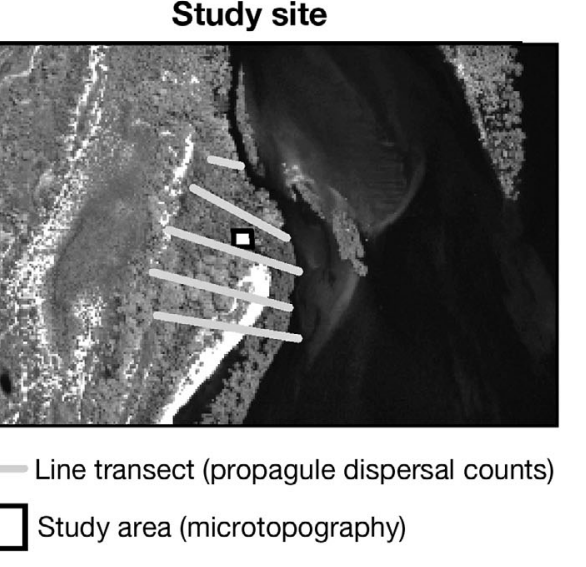

Fig. 1. Gazi Bay (Kenya) with indication of the line transects for the propagule dispersal counts and the $840 \mathrm{~m}^{2}$ study area used for microtopographical surveying. North arrow applies to all maps 
resolution of $50 \times 50 \mathrm{~cm}$ or $1 \mathrm{~m}^{2}$ within areas that are characterized by a relatively flat surface.

The first surveying method applied in the field ('traversing') consists of measuring horizontal angles and distances. In this manner 2 polygons were created, encompassing a total of 31 anchor points 1 ( 7 of which are mutual). The angle error $f_{\mathrm{a}}$ for the closure of both polygons (first anchor point $=$ last anchor point) was calculated and amounted to $-2.50^{\circ}$ and $3.32^{\circ}$ for Polygon 1 and 2 , respectively. These values were then tested to their tolerance $\tau_{\mathrm{a}}$ (calculations according to Kahmen \& Faig 1988, Bannister et al. 1998) to verify whether these values were smaller: $\tau_{a}=2.6 \sqrt{ } n \sigma_{\alpha}$ where $\sigma_{\alpha}=$ deviation on an angle measurement and $\mathrm{n}=$ number of angles.

For Polygon 1 and 2 respectively, $\tau_{\mathrm{a}}$ had a value of $6.10^{\circ}$ and $3.68^{\circ}$, meaning that $f_{\mathrm{a}}$ can be divided evenly amongst all the anchor points in order to actually 'close' the polygon.

The same procedure was applied for the distance error $f_{\mathrm{L}}$ (calculations according to Kahmen \& Faig 1988, Bannister et al. 1998) which added up to $1.06 \mathrm{~m}$ for Polygon 1 and $0.20 \mathrm{~m}$ for Polygon 2, while the tolerance $\tau_{\mathrm{L}}$ was higher for both Polygon $1(1.20 \mathrm{~m})$ and 2 $(0.81 \mathrm{~m})$.

Having satisfied these conditions, this preliminary polygon network could then be expanded to the second phase.

In a second stage, 29 sub-points and a substantial number of detail points were surveyed using distance measurements, placing the optical level in the unknown points and determining stadiametric distances to known points. The main prerequisite of this method is the minimum number of 2 distance measurements towards 2 known points, so during this field work these points were linked to 3 or more anchor points, allowing us to apply the least squares method with the aim of generating more accurate results through superfluous measurements (calculations according to Kahmen \& Faig 1988, Alberda 1991, Bannister et al. 1998). Finally, for each point the height measurements were simultaneously achieved by means of the method 'geometric levelling', which takes into account the collimation errors (calculations according to loc. cit.). Collimation errors occur when the collimation axis is not fully horizontal when the instrument is level. These errors are eliminated when sight lengths are kept equal, which is the case with geometric levelling. Furthermore, for a typical collimation error of $20 "$, over a sight length of $50 \mathrm{~m}$ the effect is $5 \mathrm{~mm}$, but for smaller distances, as within this study area, errors can be considered negligible (Kahmen \& Faig 1988).

\footnotetext{
1 An anchor point is a point within an irregular polygon constructed by means of planimetric polygonation, by measuring the horizontal distances and angles
}

Construction of a DTM: In total, 5315 points were measured, which were then checked for errors and converted to a set of points with an $x, y$ and $z$ value, describing the position in a planimetric $(x, y)$ and an altimetric (z) plan. After visualizing the total number of points, 67 detail points were discarded since they appeared outside the study area and were likely to generate further errors. The remaining measurements served as an input to create a Triangular Irregular Network (TIN), a set of triangles that are connected by their sides and that each have a particular (irregular) shape and slope in a 3D space. The TIN-construction was based on the (non-constrained) Delauney triangulation of the original set of points by use of Voronoi diagrams (see Raper 1990, McCoy \& Johnston 2002).

Height above datum (HAD): Since the use of a differential global positioning system to vertically georeference the area was not possible due to the high canopy coverage, the relative elevations were converted to absolute HAD using alternative field experiments. Dry strips of ecoline-dyed paper were fixed along one of the major trunks or aerial roots of 5 Rhizophora trees, each of which overlaid a detail point, and monitored during 7 consecutive days. As ecoline dissolves in water, the mark of dissolved and undissolved ecoline on the strips indicated the height of the previous high tide. Since monitoring took place during the day, this measurement was limited to the highest tide of current diurnal or previous nocturnal tide. Finally, by using the documented Kilindini tide tables, the approximate absolute height of the water could be calculated and the relative elevations in the DTM converted to approximate absolute field topography. The data concerning the water level heights are derived from the Kenya Ports Authority that annually publishes the tide tables in which heights, relative to the datums of the largest scale Admiralty charts of Port Mombasa, Kilindini $\left(4^{\circ} 4^{\prime} \mathrm{S}, 39^{\circ} 39^{\prime} \mathrm{E}\right.$, approximately $45 \mathrm{~km}$ north of the study area Gazi Bay), are tabulated for all tides with an indication of the time at which they occur (Kenya Ports Authority 2002). Though tide predictions data are also available from the nearest Secondary Port, Wasini Island $\left(4^{\circ} 39^{\prime} \mathrm{S}, 39^{\circ} 39^{\prime} \mathrm{E}\right.$, approximately $25 \mathrm{~km}$ south of Gazi Bay), we opted for those from the Standard Port, Port Mombasa (Kilindini), because data from Secondary Ports are extremely variable in quality. Furthermore, the published Admiralty charts document the differences in mean high water at spring tide (MHWS), mean high water at neap tide (MHWN), mean low water at neap tide (MLWN) and mean low water at spring tide (MLWS) between the Standard Port (Kilindini) and the Secondary Port (Wasini Island) respectively as following $+0.1 \mathrm{~m},+0.1 \mathrm{~m},+0.1 \mathrm{~m}$ and $0.0 \mathrm{~m}$. Since Gazi Bay is situated between these ports, we considered these differences negligible for our 
study and decided on the predicted tidal data of the Standard Port, Kilindini, which provides an adequate local prediction of the tide, instead of the less reliable data from the Secondary Port. In some enclosed and shallow bay systems such as Gazi Bay, height differences between actual tidal amplitude and tide table predictions can occur, but besides the documented differences between the Standard Port and the Secondary Port, we note that the height measurements within the study area are very detailed and possible height differences do not influence the outcome of this paper because both DTM and IPCC sea level rise scenario are derived from the same tide predictions and so relative height differences (which are most important in this study) remain the same. Finally, considerable significant differences between predicted tidal heights and actual heights can occur when meteorological conditions differ from the average and extreme weather events arise. Variations in tidal heights are mainly caused by very strong or prolonged winds and by unusually high or low barometric pressure, which was not the case during the year in which the measurements were taken.

Field survey of the vegetation. The aim of the vegetational survey was to map the exact position of each adult tree in the study area. Using coconut-wire the ca. 0.1 ha area was divided into grid cells of $5 \times 5 \mathrm{~m}$, which were further divided into $1 \mathrm{~m}^{2}$ cells at the time of mapping. Mapping within each square meter was done using a measuring tape. The exact position of stems taller than $1.3 \mathrm{~m}$ and with a diameter at $130 \mathrm{~cm}$ trunk height $\left(D_{130}\right)$ greater than $2.5 \mathrm{~cm}$ was indicated on paper preprinted with the same grid. Along with the $D_{130}$, the species identity was also noted, and the extent of prop roots were drawn to scale on the millimeter paper. The total coverage of the canopy in all quadrats of $10 \times 10 \mathrm{~m}$ was between 80 and $100 \%$. These percentages were estimated and compared by the 2 people working in the field, meaning that both faced upwards from the centre of the quadrat and gave an approximation of the adult coverage encompassing the $10 \times 10 \mathrm{~m}$, as applied in the Braun-Blanquet method (Kent \& Coker 1992). The latter measurements were directly implemented in several shapefiles by means of ArcGIS 8.2.

Propagule counts. Our 3 null hypotheses were as follows:

All propagules are equally distributed and have no preference for a specific site.

There is no difference between the 2 Rhizophoraceae species regarding suitability of the environment for establishment.

Propagules establish equally through stranding and self-planting.

Parallel with the ongoing daily topographical measurements, successive propagule counts were carried out in February-March 2002 both at 4 d intervals and in a total of 35 permanent quadrats. The elevation above mean low water was assumed to be the predominant environmental factor affecting the distribution of mangrove trees, and so line transects following this altitude gradient (perpendicular to the coastline) were used to set the different quadrats for the propagule counts (Fig. 1). These line transects were positioned according to a previous study in Gazi Bay by DahdouhGuebas et al. (2004a) where the vegetation structure in different layers was determined. The selection of the quadrats was based on different settings of (1) root complexity (prop roots, pencil roots, no roots), (2) soil texture (sand, silt or clay dominated) and (3) slope (gentle slope $<5^{\circ}$, medium slope between 6 and $25^{\circ}$, and strong slope $>25^{\circ}$ ). It was not our intention to classify soil texture according to soil percentage, but to observe the upper soil layer and assign it to 1 of 3 possible classes (sand, silt or clay). The category 'sand' is very clear considering the light yellow colour and the coarse structure, while the structure of clay is much darker and more compact and the smell reveals the presence of $\mathrm{H}_{2} \mathrm{~S}$. The remaining quadrats were categorized as silt dominated. The factor 'slope' was determined by means of a clinometer. The combination of these factors in different quadrats was examined in order to estimate the effect of these environmental settings on the suitability for propagules to strand or self-plant naturally under these conditions.

Other distinctions were also made according to the position (stranded or self-planted) and the species (Rhizophora mucronata and Ceriops tagal). In the sites tidally comparable to our mapped area, and located in the adjacent wider mangrove forest (Fig. 1), areas differing in just one of these conditions (while the other ones remained constant) were not always available. It is recognised that these counts also depend on the seasonal availability of propagules.

The effect of the environmental conditions on propagule stranding suitability was tested using 1-way ANOVA, Univariate tests and MANOVA ( $\alpha=0.05)$. These tests were applied after completing a Levene's test and a Kolmogorov-Smirnov test to certify that the data satisfied the basic statistical assumptions (i.e. homoscedasticity and normal distribution, respectively).

Furthermore, in order to structure the data set concerning propagule counts and to distinguish the variation in species data (Rhizophora mucronata and Ceriops tagal) in relation to the environmental variables (substrate, slope and root complex), a direct gradient analyses was conducted by means of CANOCO 4.5. When carrying out a canonical correspondence analysis (CCA), the sum of all eigenvalues added up to 1.61 and, since this value was smaller than 4 , the analysis 
was conducted by means of a redundancy analysis (RDA) (ter Braak \& Smilauer 2002).

GIS based water level simulations and stranding suitability. The main objectives and methodology of the GIS analyses were designed to investigate the following conditions (a general summary of the processes within ArcGIS is shown in Fig. 2).

Suitable regions for stranding and self-planting of propagules: Considering the different factors (slope, substrate and root complex), the statistical analyses revealed the combined settings where propagules of each species, Ceriops tagal and Rhizophora mucronata, tend to have the most, less or least chance of stranding after dispersion by water or to self-plant after falling from their parental tree. We defined suitability as the ease with which a propagule could reach a particular site by stranding or self-planting, and become entangled by certain structures. Previous information is implemented in ArcGIS 8.2 where the different shapefiles of each abiotic factor are combined to a suitability map for either C. tagal or R. mucronata, based on an assembled table derived from the statistical analyses. This table contains values of 1 (most suitable), 2 (suitable) or 3 (least suitable) and represents a decrease of possible self-planted or stranded propagules from 1 to 3, but even in the 'least suitable' area it is possible that a propagule sporadically strands or self-plants. The areas that are very suitable encompass the most favourable characteristics for stranding or self-planting of propagules, but we also verified whether these areas are actually accessible to propagules carried by local currents through the function 'WaterShed' in ArcGIS 8.2.

Influence of degradation (cutting) on the dispersal of propagules: The possible influences of degradation within the study area were investigated by creating a hypothetical scenario in which all trees of the species Rhizophora mucronata within the area are cut down. The trees of the species Ceriops tagal will hypothetically still be present but their root complex occupies a much smaller basal area. The implications of clearfelling are discussed in the 'Introduction'.

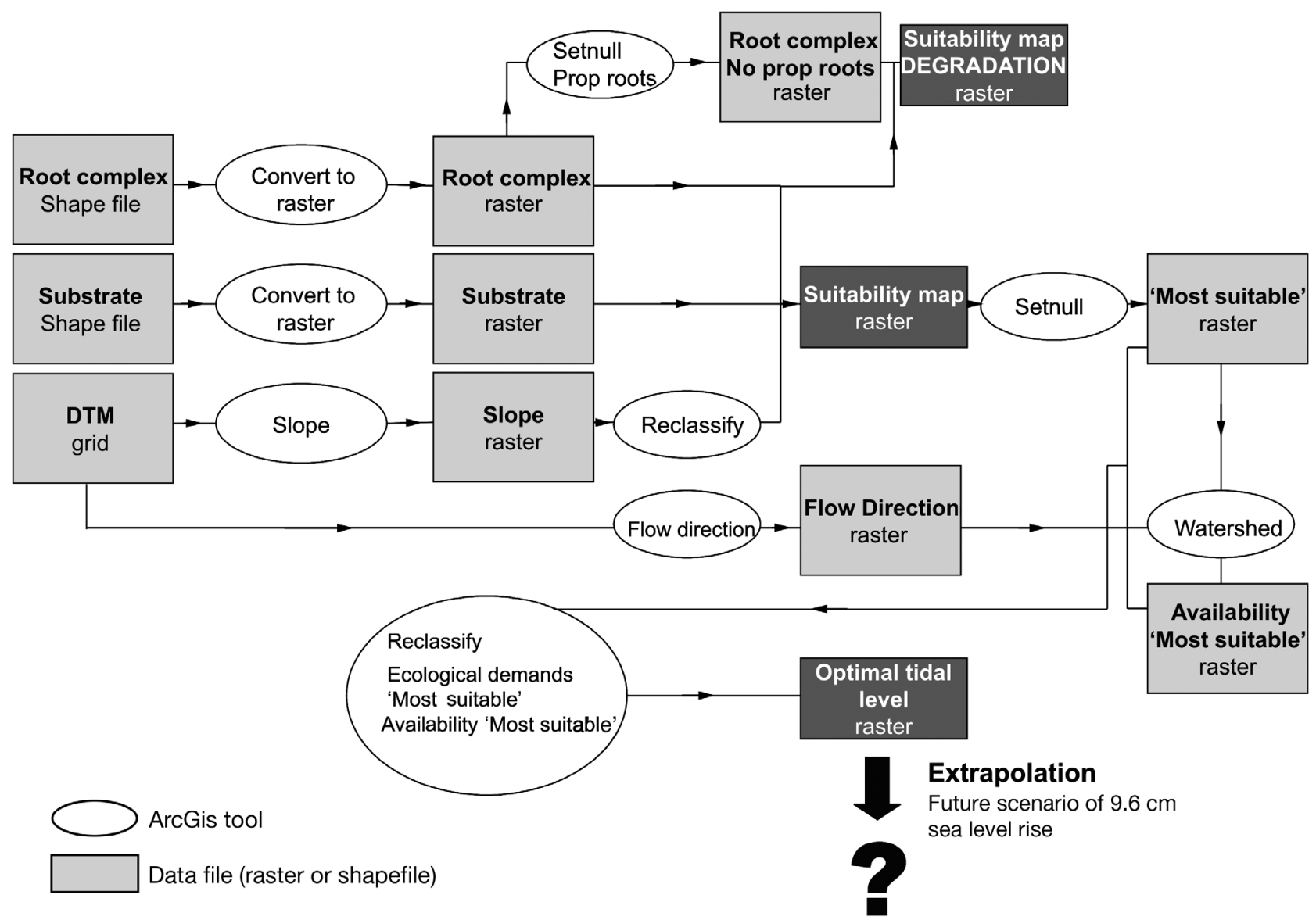

Fig. 2. Methodology applied by means of ArcGIS 8.2 in order to obtain the suitability maps for propagule dispersal, and to investigate the influence of degradation (cutting) and sea level rise on these processes 
Influence of water level modifications on the structure of mangroves: The possible influences of changing tidal levels were evaluated by simulating water level fluctuations in ArcGIS 8.2. The simulations give information concerning the 'land/water ratio', a factor with a high ecological importance when it comes to vegetation structure dynamics and explaining possible variations in vegetation data. First of all, we checked which tidal level is most favourable for the supply of propagules to the most suitable areas under the current conditions. The current situation was then compared with a possible future scenario that would take place within a time span of $20 \mathrm{yr}$ a period in which mangroves can establish without undergoing drastic changes. A sea level rise of $4.8 \mathrm{~mm} \mathrm{yr}^{-1}$ was presupposed according to a conservative and realistic scenario from the IPCC, values also referred to by Woodroffe (1990) and Nicholls et al. (1999). Over a time span of $20 \mathrm{yr}$ this would add up to a $9.6 \mathrm{~cm}$ rise. Bearing in mind the reductionistic approach, the following scenarios (both under current and future conditions) were studied: 'What is the land/water ratio for each scenario?', 'Will the sea level rise scenario cause a significant modification in the dispersal of propagules?', and 'If not, which structural changes in the vegetation might be the outcome?'.

\section{RESULTS}

\section{DTM and vegetation map of the study area}

Throughout the whole study area, where Rhizophora mucronata and Ceriops tagal are the most prominent, 317 adult mangrove trees were located and measured. These species represent respectively 44.2 and $42.3 \%$ of the total number of mangrove trees present. In view of the clear zonation pattern in Gazi, with an inland zone of Avicennia marina, a mixed zone of A. marina + $C$. tagal $+R$. mucronata, a zone of $R$. mucronata and more seaward another $A$. marina zone and a marginal zone of Sonneratia alba (Gallin et al. 1989, Van Speybroeck 1992, Dahdouh-Guebas et al. 1999, 2002a,b, $2004 a, b)$, we can describe this study area as situated in the mixed zone A. marina + C. tagal + R. mucronata.

As the extent of prop roots, stilt roots and remaining area without roots were drawn to scale on millimeter paper, this information was digitized by means of ArcGIS 8.2 into a shapefile of polygons covering the whole area. Visualisation together with the vegetation and the DTM is shown in Fig. 3. The total coverage of the different root systems can be summed up to $59.2 \%$ prop roots, $10.7 \%$ pencil roots and $30.1 \%$ of the area without roots. Concerning the slope values derived from the DTM, gentle and strong slopes occupy 32.1 and $8.3 \%$, respectively.

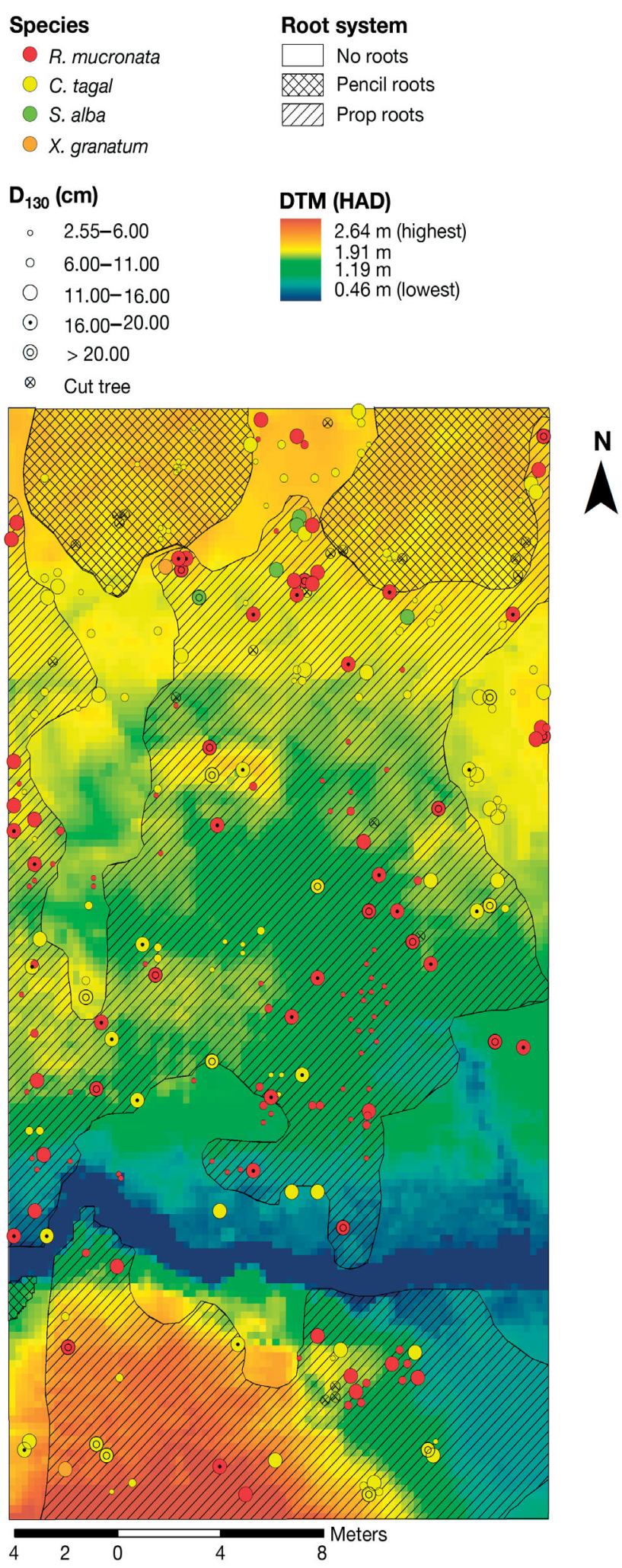

Fig. 3. Digital terrain model (DTM) of the study area in Gazi Bay overlaid by the trees (Rhizophora mucronata, Ceriops tagal, Sonneratia alba, Xylocarpus granatum) and root complex present. $\mathrm{HAD}=$ height above datum, $\mathrm{D}_{130}=$ diameter at $130 \mathrm{~cm}$ 


\section{Propagule counts}

From the several statistical analyses, we can conclude that all 3 null hypotheses (see 'Introduction') can be rejected. First of all, propagules are not all distributed equally, but displayed a preference for sites with certain features. The most favourable combinations, derived from the significance values of these tests and the descriptive statistics, are the following: 'prop roots + clay + Ceriops tagal', 'pencil roots + silt + Rhizophora mucronata' and 'gentle slope + clay $+C$. tagal', 'gentle slope + silt $+R$. mucronata', 'silt + pencil roots + stranded' and 'clay + prop roots + self-planted'. Secondly, C. tagal and R. mucronata have a clear preference for 'prop roots + clay' and 'pencil roots + silt' respectively. Furthermore, we encountered on average more stranded than self-planted propagules, and stranded propagules tended to occur in 'pencil roots', 'silt' or 'clay' in flat areas, whilst self-planted propagules (mostly C. tagal) are more often located in regions with 'prop roots' and 'clay'.

Additional results from the RDA show that (1) there is a clear division between the propagules of Ceriops tagal and Rhizophora mucronata (C. tagal shows a higher separation between the self-planted and the

Table 1. Overview of the different combinations of factors (substrate, slope and root complex [RC]) and the associated scores concerning the propagule dispersal suitability. These scores are a synthetic conclusion derived from our 3 null hypotheses (see 'Materials and methods: Propagule counts'). $1=$ most suitable, $2=$ less suitable and $3=$ least suitable (these scores will be used in the following GIS analyses), na = not applicable (combination did not occur in our study site)

\begin{tabular}{|c|c|c|c|c|}
\hline \multicolumn{3}{|c|}{ Factor } & \multicolumn{2}{|c|}{ Suitability } \\
\hline Substrate & Slope & $\mathrm{RC}$ & C. tagal & R. mucronata \\
\hline \multirow[t]{9}{*}{ Silt } & \multirow[t]{3}{*}{ Gentle } & Prop roots & 1 & 1 \\
\hline & & Pencil roots & 2 & 1 \\
\hline & & No roots & 2 & 2 \\
\hline & \multirow[t]{3}{*}{ Medium } & Prop roots & 2 & 2 \\
\hline & & Pencil roots & 3 & 2 \\
\hline & & No roots & 3 & 3 \\
\hline & \multirow[t]{3}{*}{ Strong } & Prop roots & 2 & 2 \\
\hline & & Pencil roots & 3 & 2 \\
\hline & & No roots & 3 & 3 \\
\hline \multirow[t]{9}{*}{ Sand } & \multirow[t]{3}{*}{ Gentle } & Prop roots & 2 & 1 \\
\hline & & Pencil roots & 3 & 2 \\
\hline & & No roots & 3 & 2 \\
\hline & \multirow[t]{3}{*}{ Medium } & Prop roots & 2 & 2 \\
\hline & & Pencil roots & 3 & 2 \\
\hline & & No roots & 3 & 3 \\
\hline & \multirow[t]{3}{*}{ Strong } & Prop roots & 2 & 2 \\
\hline & & Pencil roots & na & na \\
\hline & & No roots & 3 & 3 \\
\hline
\end{tabular}

stranded propagules); and (2) the variation between the species is mainly determined by the environmental variable 'substrate'; preference of $R$. mucronata is for the category 'silt dominated' whilst $C$. tagal inclines towards clay dominated areas.

The Appendix contains a detailed review of the statistical results (available online as MEPS Supplementary Material at: www.int-res.com/articles/suppl/ m356p175_app.pdf), and Table 1 summarises the scores, derived from the conclusions of the previous hypotheses, which were adapted in the spatial analyses by means of ArcGIS 8.2.

\section{GIS based water level simulations and stranding suitability}

Suitable regions for stranding and self-planting of propagules. The suitability maps (Fig. 4) of Rhizophora mucronata and Ceriops tagal represent the regions within the study area where propagules of the latter species have the most, less or least chance of being found after dispersion by water or of selfplanting after falling from the parental tree. The category 'most suitable' occupies a larger percentage of the total area surface for $R$. mucronata $(35.4 \%)$, although there is no major difference from that for $C$. tagal $(25.7 \%)$. As suggested in the results concerning the propagule counts, the main variation between these 2 species is caused by the factor 'substrate' (silt dominated vs. clay dominated), but since we only found silt dominated and sand dominated substrates within the study area, the variation is small. The areas occupied by the most suitable areas for $R$. mucronata and C. tagal were 215.9 and $297.4 \mathrm{~m}^{2}$, respectively, whilst the less suitable areas represent the biggest part of the total area (350.3 and $416.6 \mathrm{~m}^{2}$, respectively).

Influence of degradation (cutting) on the dispersal of propagules. The elimination of the prop roots of $R h i$ zophora mucronata has a substantial effect on the composition of the suitability maps (Fig. 4): the most suitable areas have completely disappeared for Ceriops tagal, whilst only a negligible percentage $(0.2 \%)$ remains for $R$. mucronata. Considering the less suitable areas under the hypothetical scenario of decreased root complexity, $R$. mucronata shows the highest value (R. mucronata: $60.7 \%$; C. tagal: $50.4 \%$ ).

Effect of water level modifications on the structure of mangroves. Fig. 5 shows the most favourable tidal level for the current situation concerning the supply of Ceriops tagal propagules to the most suitable regions (the same procedure was performed for Rhizophora mucronata). Higher tidal levels would most probably relocate a number of the propagules to the northern 


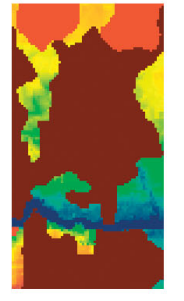

(d) C. tagal

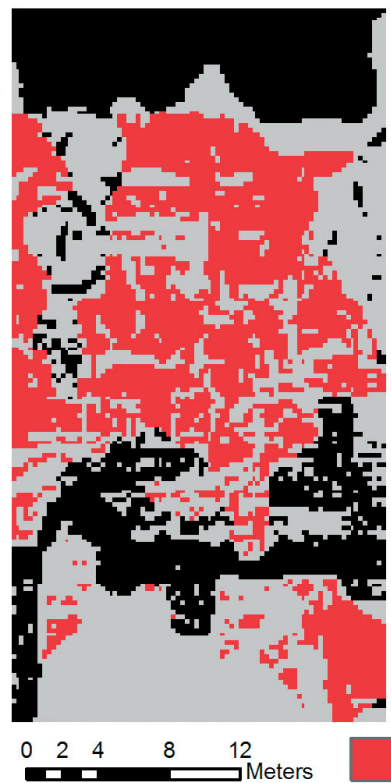

(e) R. mucronata

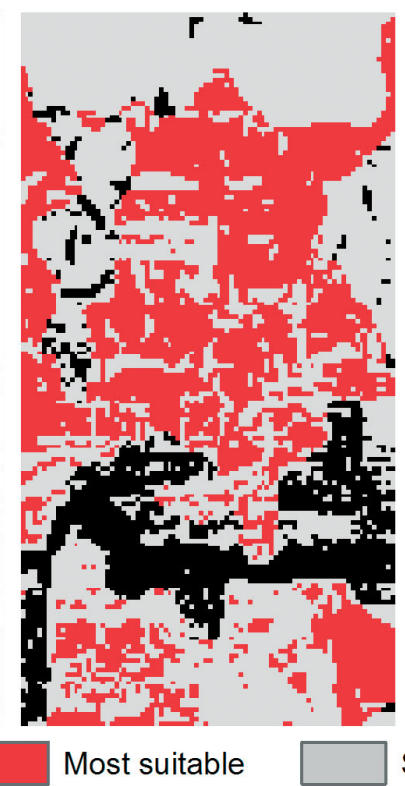

(b) Slope

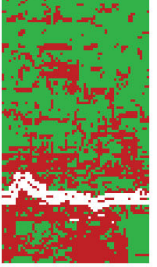

(c) Substrate

\begin{tabular}{ll} 
Gentle \\
Medium \\
\hline & Strong
\end{tabular}
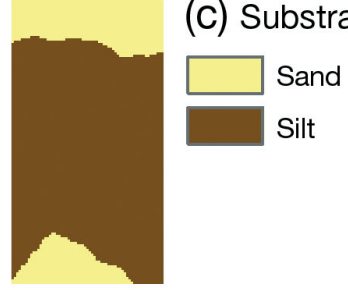

Silt (f) C. tagal
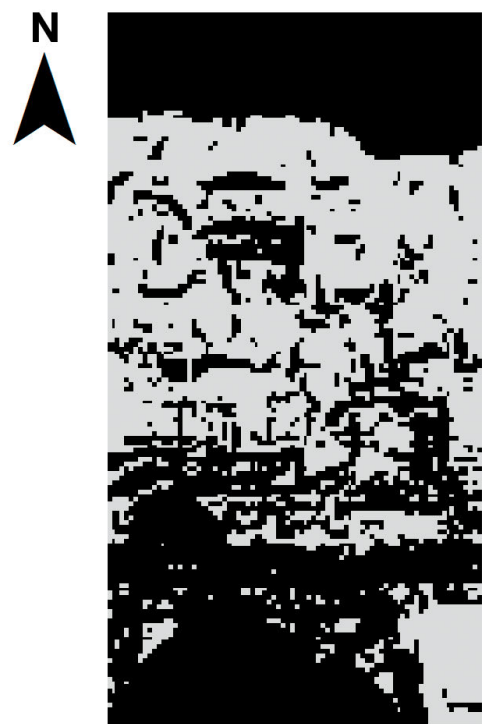

(g) R. mucronata

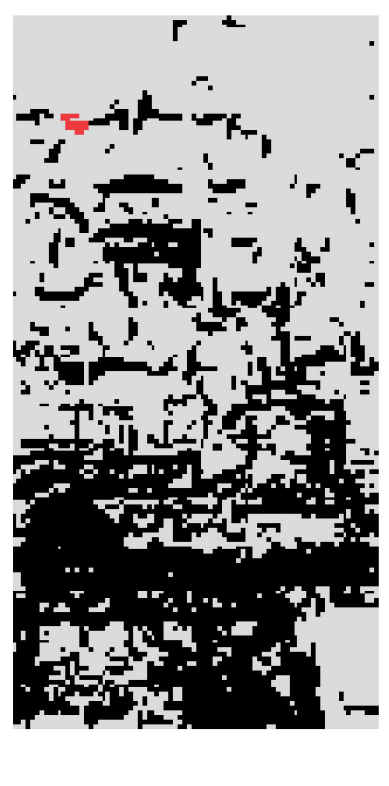

Fig. 4. Maps of (a) root complex, (b) slope and (c) substrate, here, and the score chart (Table 1), are combined in ArcGIS 8.2. to obtain the suitability maps for propagule dispersal of (d) Ceriops tagal and (e) Rhizophora mucronata. (f,g) Influence of degradation (cutting) on suitability for propagule dispersal of (f) C. tagal and (g) R. mucronata. North arrow applies to all maps

(a)

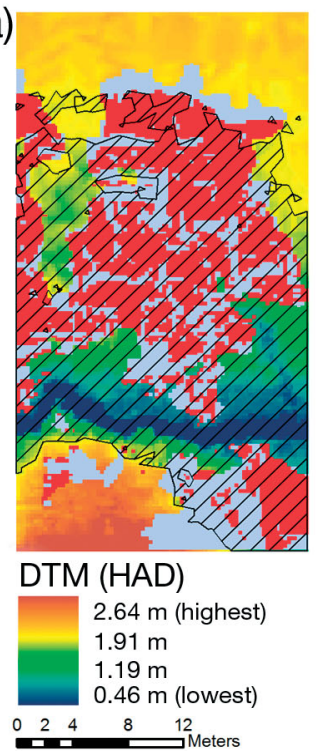

(b)

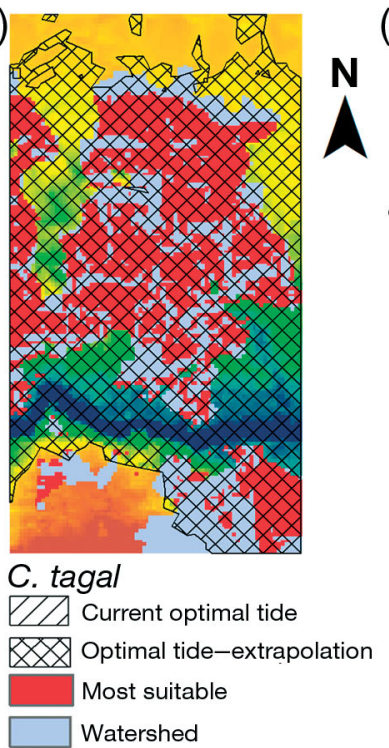

(c) 500

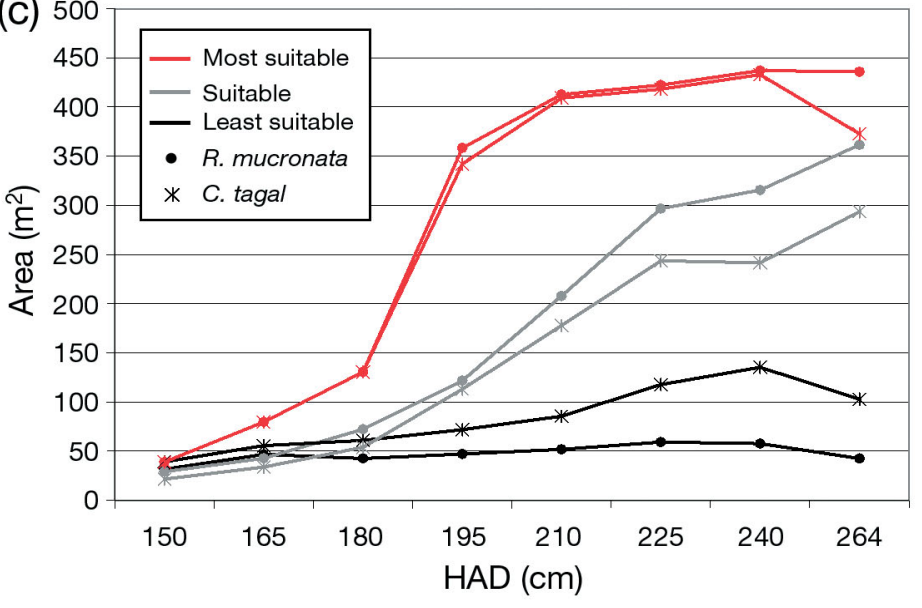

Fig. 5. Following observation of the most suitable regions for propagule dispersal and their watershed, the most optimal tidal level height above datum (HAD) $(2.01 \mathrm{~m})$ was (a) obtained for the current situation and (b) extrapolated (2.11 m HAD) to a future scenario where sea level rises by $9.6 \mathrm{~cm}$ (example for Ceriops tagal). (c) Area of suitability (within the total surveyed area of $840 \mathrm{~m}^{2}$ ) at different HAD for C. tagal and Rhizophora mucronata. North arrow applies to both maps 
regions where the conditions for stranding are least favourable.

When considering the future scenario, where sea level rises by $9.6 \mathrm{~cm}$ over a period of $20 \mathrm{yr}$ (Fig. 5), the tidal levels provide a substantially larger inundation area (land/water ratio, Table 2). For both species (but especially $R$. mucronata) a sea level rise could possibly cause a modification in the distribution of the propagules within the whole study area. The map shows that an extrapolation of the optimal tidal level (as in current conditions) expands the reach of the most suitable regions, which means that a gradual withdrawal of the water can leave propagules to strand in the least suitable northern regions. This hypothetical scenario, representing a minimum sea level rise of $4.8 \mathrm{~mm} \mathrm{yr}^{-1}$, could alter the distribution pattern of the juvenile vegetation layer within a time span of $20 \mathrm{yr}$, which could lead to noticeable floristic modifications from a regional point of view.

\section{DISCUSSION}

The results from the various statistical tests demonstrate that each of the environmental factors (slope, substrate and root complex) has a significant influence on the suitability of the mangrove floor for juvenile propagules. The most favourable category for propagule establishment was determined for each factor: prop roots and pencil roots clearly have the ability to entangle propagules in their structures (see also Dahdouh-Guebas \& Koedam 2006); flat areas and substrates with a more compact soil structure (clay, silt) can hold propagules better. These findings bring us one step closer towards closing the knowledge gap regarding the period between the mature, falling propagule and its establishment.

It was also clear that in all possible situations more stranded propagules were encountered, yet we cannot totally exclude a significant presence of self-planted propagules since they appear frequently in plots that contain prop roots. Furthermore, propagules possibly self-plant near their parental trees, but sometimes they may not necessarily be anchored firmly enough in

Table 2. Optimal tidal level height above datum (HAD) (m) and the land/water ratio for the species Ceriops tagal and Rhizophora mucronata under the current situation and possible future scenario of sea level rise

\begin{tabular}{|lcccc|}
\hline \multirow{2}{*}{ Species } & \multicolumn{2}{c}{ Current situation } & \multicolumn{2}{c|}{ Future scenario } \\
& $\begin{array}{c}\text { Optimal HAD } \\
(\mathrm{m})\end{array}$ & $\begin{array}{c}\text { Land/water } \\
\text { ratio }\end{array}$ & $\begin{array}{c}\text { Optimal HAD } \\
(\mathrm{m})\end{array}$ & $\begin{array}{c}\text { Land/water } \\
\text { ratio }\end{array}$ \\
\hline C. tagal & 2.01 & $1: 1.84$ & 2.11 & $1: 4.01$ \\
R. mucronata & 2.11 & $1: 4.01$ & 2.21 & $1: 11.49$ \\
\hline
\end{tabular}

the substrate. Within a time span of $4 \mathrm{~d}$ (time interval between 2 measurements) they could have been washed away by the incoming tides, especially at the seaward side where the wave action is highest. Propagules of Ceriops tagal are often found self-planted, especially on the landward side where the wave action is lowest. These propagules are thinner and sharper than the heavier propagules of Rhizophora mucronata, which apparently gives them the advantage to selfplant. Previous conclusions link up with the theory according to Van Speybroeck (1992), which states that both stranding and self-planting can occur simultaneously within a mangrove forest. Considering the dispersal characteristics of propagules, it is also essential to bear in mind their dispersal potential including weight, form, orientation, buoyancy and time to take root (Tomlinson 1986, Clarke 1993, Clarke \& Myerscough 1993, Clarke et al. 2001).

In a wider framework of vegetation structure dynamics, it is of great importance to generate reliable predictions on the current status of a mangrove forest. As shown in the synthetic scheme (Fig. 6), a naked $(1$ or unsuitable site 2 within a mangrove forest needs to overcome a critical step to (re-)enter a positive cycle of development and self maintenance. This step can be naturally or artificially induced; either way it will lead to a development of a forest nucleus $(3$ within the naked site (Situation 1) or an expansion of the mangrove forest 4 through an improvement of the unsuitable regions (Situation 2). When considering the natural development, both situations require an adequate natural maintenance, improving forest resilience through tidal distribution $(5$ or self-planting 6 of the propagules. When propagules are transported by tidal currents or self-planted when falling from the adult tree, propagule recruitment may occur if the dispersal units first of all arrive in a suitable area $\boldsymbol{( 7}$ and if other factors, including predation (Smith 1987, DahdouhGuebas et al. 1997, 1998, Lee 1998), interspecific competition, frequency of inundation and physico-chemical characteristics of the surface (Delgado et al. 2001), are favourable. Propagule recruitment, closing the positive cycle, drives natural rejuvenation and therefore further development and self maintenance of a mangrove forest. However, when propagules are firmly self-planted under the parental tree, this can only lead to a contiguous forest expansion $\mathbf{8}$, whilst a tidal distribution can also initiate a new forest nucleus in a naked site $\boldsymbol{9}$ further afield.

The suitability maps created for Ceriops tagal and Rhizophora mucronata show that under current circumstances a large proportion of the study area is very suitable for the stranding or self- 

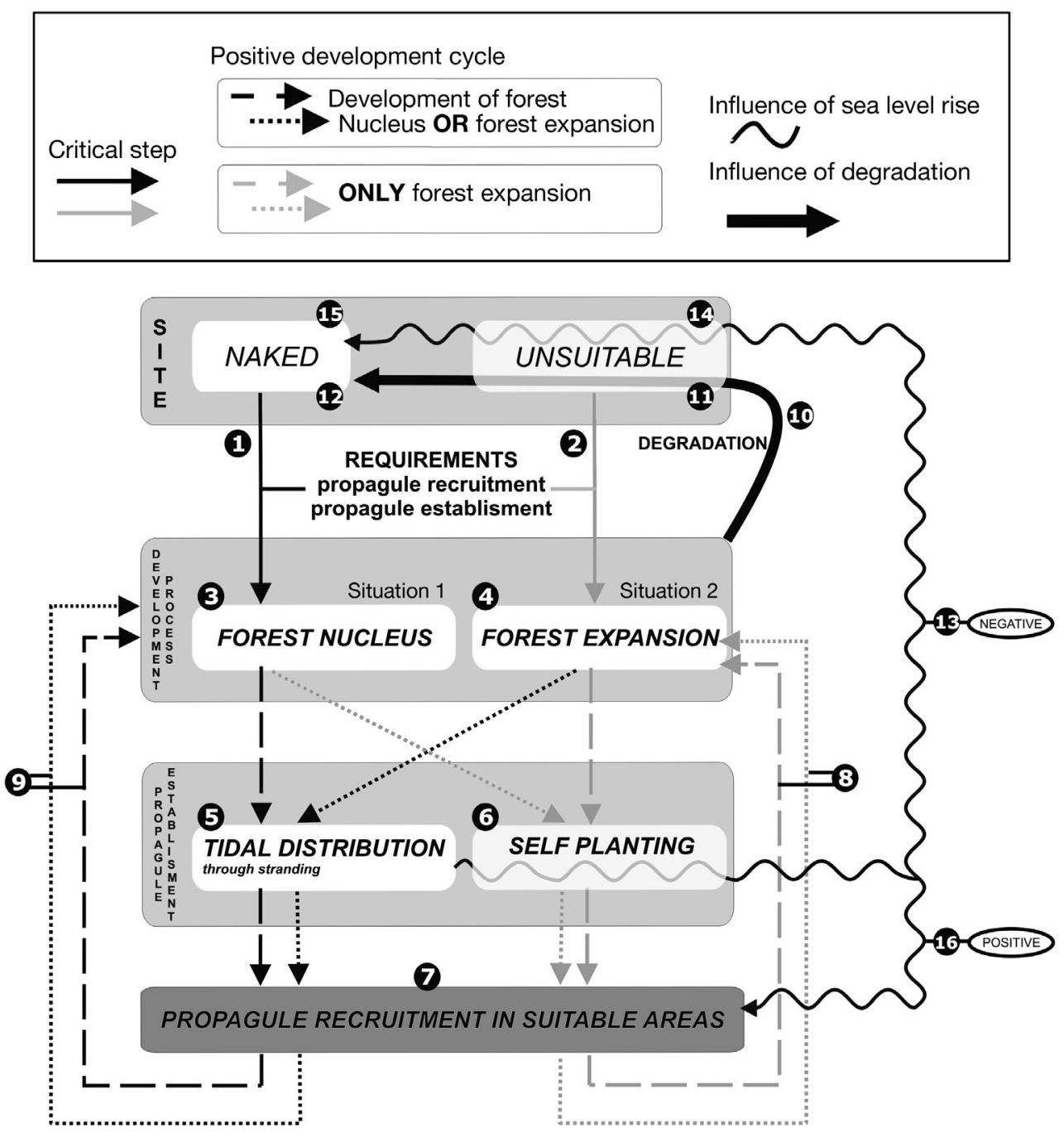

Fig. 6. Synthetic scheme of the positive development cycle concerning propagule recruitment in suitable areas (through stranding or selfplanting), with the influence of degradation (cutting) and sea level rise. See 'Discussion' for detailed explanation

planting of propagules and self-maintenance is likely. These areas have the potential to successfully regenerate, yet the question remains whether the same areas are also suitable for the further development and growth of the propagules. The establishment and survival success is dependent on many factors, as stated in the previous paragraph. Furthermore, research along the Kenyan coast has shown that the development of mangrove seedlings does not occur randomly within the intertidal region, but is restricted to areas where the parental trees are present (e.g. Gallin 1988, Van Speybroeck 1992, Dahdouh-Guebas et al. 2002a,b, Dahdouh-Guebas \& Koedam 2006). Even when the parental trees have been cut down, seedling development only takes place within the species-specific distribution zone (Van Speybroeck 1992). Since the study area is situated within a mixed zone of Avicennia marina $+C$. tagal $+R$. mucronata, we can assume that seedling development is favourable since the parental trees are present for both species.
Another important factor is light: the study area is mainly covered by the canopy of the adult trees and although both species show a greater chance of survival in areas with more light, the chance of survival is significantly higher for $R$. mucronata, explaining their ability to colonize in the shade of other plants (Palihawadene \& Pinto 1989). Under current circumstances we can presume that the study area in Gazi Bay has the ability to successfully renew without human interference, however in the northern part tree cutting has left its traces. If this degradation persists, more open spaces will be created within the forest. The anchoring of propagules will be more difficult, especially on the seaward side where wave action is highest and the necessity for propagules to entangle in certain root structures is very important.

Mangrove forests are subjected to severe anthropogenic influence (Kairo 1995, Ellison \& Farnsworth 1996, Duke et al. 1997, Farnsworth \& Ellison 1997, Abuodha \& Kairo 2001, Dahdouh-Guebas et al. 2005b). 
The cutting of these trees, especially the Rhizophora spp., can lead to a serious degradation of the mangrove forest and eventually to a disconnection of the positive development cycle (10 (Fig. 6). The scale of degradation determines the setback; when trees are randomly removed from the forest, an area can easily become unsuitable (10 for stranding or self-planting of propagules, whilst tree cutting on a larger scale can create new (isolated) naked sites (12. As stated in the 'Introduction', prop and pencil roots function as traps for propagules as well as for sediment, so when trees are cut in a certain area, propagules have fewer structures to attach to after dispersion by water. Additionally, as the cutting of mangrove trees is also closely associated with a decreased stability of the soil, this can lead to erosion and therefore in certain situations (e.g. along riverbanks) consequently to steeper slopes, which we have shown to be less suitable for stranding or selfplanting of propagules. The cutting of trees in sandy areas should especially be avoided since we have confirmed that propagules are least likely to firmly fix in a coarse sand dominated surface layer, which impairs propagule establishment without any human intervention. Within Gazi Bay, many large bare and sandy sites can be found, and research by Bosire (1999) has shown that they can remain in the same state for a substantial time (at least, no colonization was observed for ca. $10 \mathrm{yr}$ ). To avoid the risk of overexploitation, it is of great importance that users of these natural resources are informed about the ecological and therefore longterm economical value of these ecosystems. Furthermore, the mangrove trees within the reach of the most suitable regions for stranding or self planting of propagules are of great value to a mangrove stand and could provide useful information for forest management concerning selective cutting of mangrove trees.

The level of the sea is not, and has never been, constant. Throughout the 20th century, sea levels have already risen by 10 to $20 \mathrm{~cm}$ on average and the Intergovernmental Panel on Climate Change (IPCC) Third Assessment Report suggested a rise of 9 to $88 \mathrm{~cm}$ by the year 2100 based on atmosphere-ocean general circulation models and emission scenarios (IPCC 2001). As mentioned in the 'Introduction', a sea level rise can have a major influence on mangrove ecosystems depending on the actual rate of the sea level rise, the sediment supply and the topography of the coastline (Woodroffe 1990, Gilman et al. 2006). When the rate of sea level rise is too high and/or when a landward expansion is hampered by an obstruction, mangrove development takes a negative turn (13 towards an unsuitable (4) or naked site (15 (Fig. 6). However, when sea level rises relative to the mangrove surface and when no obstructions are present, a positive development 16 can occur, still dependent on the local site spe- cific characteristics. Considering the hydrochorous dispersal of mangrove propagules, the hypothetical scenario of sea level rise shows that an alteration of the tidal level has a notable effect on the spatial distribution pattern of these propagules. Within the study area in Gazi Bay, the extrapolation of the optimal tidal level results in a larger inundation area where propagules can be released in the least suitable northern regions, yet these results are strongly dependent on the local microtopography. In addition to this hypothetical sea level rise scenario of $4.8 \mathrm{~mm} \mathrm{yr}^{-1}$, other researchers have concluded that the distribution pattern of the juvenile vegetation layer can alter within a time span of 20 yr. Along the Kenyan coast Rhizophora spp. are preferentially used to produce charcoal, firewood, house- and boat-building materials. However, cutting Rhizophora spp. eventually leads to a new juvenile layer dominated by Ceriops tagal (Dahdouh-Guebas et al. 2000a, Kairo 2001, Kairo et al. 2002). Moreover, in the Galle mangroves (Sri Lanka) between 1974 and 1994, a considerable area of $R$. apiculata in the central area has been changed into an open space colonized with the herbaceous plant Fimbristylis salbundia subsp. pentaptera and young Excoecaria agallocha trees (Dahdouh-Guebas et al. 2000b), i.e. nonmangrove vegetation or mangrove of socio-ecological value.

This detailed study on digital terrain modelling in mangroves was restricted to a small area within a zoned mangrove forest, but on a broader scale the applied methodology can also be a powerful tool in the study of vegetation structure dynamics. The topography within a mangrove forest may be site-specific, but other parameters (e.g. root complexity, propagule properties) are universal for mangrove ecosystems.

Acknowledgements. We thank the local people of Gazi, more specifically R. Abdul for the assistance in the field, and the Ba'alawy family for providing food and accommodation. This research was funded by the Flemish Interuniversity Council (VLIR) and D.D. has a VLIR PhD Scholarship. F.D.-G. was a Postdoctoral Researcher of Science Foundation in Flanders (FWO-Vlaanderen). This work was in part presented at (1) the International Symposium of Aquatic Vascular Plants (ISAVP) (January 11-13, 2006, Brussels, Belgium), (2) the Mangrove Macrobenthos Meeting 2 (MMM2) (June 25-30, 2006, Coolangatta, Australia) and (3) the 7th International Symposium on GIS and Computer Cartography for Coastal Zone Management (CoastGIS) (July 12-16, 2006, Wollongong, Australia).

\section{LITERATURE CITED}

Abuodha PAW, Kairo JG (2001) Human-induced stresses on mangrove swamps along the Kenyan coast. Hydrobiologia 458:255-265

Alberda JE (1991) Inleiding landmeetkunde. Delftse Uitgever Maatschappij, Delft

Badola R, Hussain SA (2005) Valuing ecosystem functions: an empirical study on the storm protection function of Bhi- 
tarkanika mangrove ecosystem, India. Environ Conserv 32(1):85-92

Bannister A, Raymond S, Baker R (1998) Surveying. Longman, Harlow

Baran E (1999) A reviews of quantified relationships between mangroves and coastal resources. Phuket Mar Biol Centre Res Bull 62:57-64

Barbier EB (2003) Habitat-fishery linkages and mangrove loss in Thailand. Contemp Econ Pol 21(1):59-77

Barbier EB, Cox M (2002) Economic and demographic factors affecting mangrove loss in the coastal provinces of Thailand, 1979-1996. Ambio 31(4):351-357

Bosire JO (1999) Floral and faunal secondary succession in a restored mangrove system in Kenya. MSc thesis, Department of Ecological Marine Management (EcoMaMa), Vrije Universiteit Brussel, Brussels

Bosire JO, Dahdouh-Guebas F, Kairo JG, Koedam N (2003) Colonization of non-planted mangroves into reforested mangrove stands. Aquat Bot 76:267-279

Chapman VJ (1976) Mangrove vegetation. J. Cramer, Vaduz, Liechtenstein

Christensen B, Wium-Andersen S (1977) Seasonal growth of mangrove trees in southern Thailand. I. The phenology of Rhizophora apiculata Bl. Aquat Bot 3:281-286

Clarke PJ (1993) Dispersal of grey mangrove (Avicennia marina) propagules in southeastern Australia. Aquat Bot 45:195-204

Clarke PJ, Myerscough PJ (1993) The intertidal distribution of the grey mangrove (Avicennia marina) in southeastern Australia: the effects of physical conditions, interspecific competition, and predation on propagule establishment and survival. Aust J Ecol 18:307-315

Clarke PJ, Kerrigan RA, Westphal CJ (2001) Dispersal potential and early growth in 14 tropical mangroves: Do early life history traits correlate with patterns of adult distribution? J Ecol 89:648-659

Coppejans E, Beeckman H, De Wit M (1992) The seagrass and associated macroalgal vegetation of Gazi Bay (Kenya). Hydrobiologia 247:59-75

Dahdouh-Guebas F (2001) Mangrove vegetation structure dynamics and regeneration. PhD dissertation, Vrije Universiteit Brussel, Brussels

Dahdouh-Guebas F, Koedam N (2002) A synthesis of existent and potential mangrove vegetation structure dynamics from Kenyan, Sri Lankan and Mauritanian case-studies. Meded Zitt K Acad Overzeese Wet/ Bull Séanc Acad R Sci Outre-Mer 48(4):487-511

Dahdouh-Guebas F, Koedam N (2006) Empirical estimate of the reliability of the use of the Point-Centred Quarter Method (PCQM): solutions to ambiguous field situations and description of the PCQM + protocol. For Ecol Manag 228:1-18

Dahdouh-Guebas F, Verneirt M, Tack JF, Koedam N (1997) Food preferences of Neosarmatium meinerti de Man (Decapoda: Sesarminae) and its possible effect on the regeneration of mangroves. Hydrobiologia 347:83-89

Dahdouh-Guebas F, Giuggioli M, Oluoch A, Vannini M, Cannicci S (1998) Feeding habits of non-ocypodid mangrove crabs from Kenya. Bull Mar Sci 64(2):291-297

Dahdouh-Guebas F, Coppejans, E, Van Speybroeck D (1999) Remote sensing and zonation of seagrasses and algae along the Kenyan coast. Hydrobiologia 400:63-73

Dahdouh-Guebas F, Mathenge C, Kairo JG, Koedam N (2000a) Utilization of mangrove wood products around Mida Creek (Kenya) amongst subsistence and commercial users. Econ Bot 54(4):513-527

Dahdouh-Guebas F, Verheyden A, De Genst W, Hettiarachchi
S, Koedam N (2000b) Four decade vegetation dynamics in Sri Lankan mangroves as detected from sequential aerial photography: a case study in Galle. Bull Mar Sci 67(2):741-759

Dahdouh-Guebas F, Kairo JG, Jayatissa LP, Cannicci S, Koedam N (2002a) An ordination study to view vegetation structure dynamics in disturbed and undisturbed mangrove forests in Kenya and Sri Lanka. Plant Ecol 161(1):123-135

Dahdouh-Guebas F, Verneirt M, Cannicci S, Kairo JG, Tack JF, Koedam N (2002b) An exploratory study on grapsid crab zonation in Kenyan mangroves. Wetlands Ecol Manag 10:179-187

Dahdouh-Guebas F, Van Pottelbergh I, Kairo JG, Cannicci S, Koedam N (2004a) Human-impacted mangroves in Gazi (Kenya): predicting future vegetation based on retrospective remote sensing, social surveys, and distribution of trees. Mar Ecol Prog Ser 272:77-92

Dahdouh-Guebas F, De Bondt R, Abeysinghe PD, Kairo JG, Cannicci S, Triest L, Koedam N (2004b) Ecologic-comparative study of the disjunct zonation pattern of the grey mangrove Avicennia marina (Forsk.). Bull Mar Sci 74(2): $237-252$

Dahdouh-Guebas F, Jayatissa LP, Di Nitto D, Bosire JO, Lo Seen D, Koedam N (2005a) How effective were mangroves as a defence against the recent tsunami? Curr Biol 15(12): R443-447

Dahdouh-Guebas F, Hettiarachchi S, Sooriyarachchi S, Lo Seen D, Batelaan O, Jayatissa LP, Koedam N (2005b) Transitions in ancient inland freshwater resource management in Sri Lanka affect biota and human populations in and around coastal lagoons. Curr Biol 15(6):579-586

Delgado P, Hensel PF, Jiménez JA, Day JW (2001) The importance of propagule establishment and physical factors in mangrove distributional patterns in a Costa Rican estuary. Aquat Bot 71: 157-178

Duke NC (1990) Phenological trends with latittude in the mangrove tree Avicennia marina. J Ecol 78: 113-133

Duke NC, Pinzón M, Prada MC (1997) Large-scale damage to mangrove forests following two large oil spills in Panama. Biotropica 29(1):2-14

Egler FE (1948) The dispersal and establishment of red mangroves, Rhizophora in Florida. Caribb For 9(4):229-320

Ellison AM (2000) Mangrove restoration: Do we know enough? Restor Ecol 8: 219-229

Ellison AM, Farnsworth EJ (1996) Anthropogenic disturbance of Caribbean mangrove ecosystems: past impacts, present trends, and future predictions. Biotropica 28(4):549-565

Farnsworth EJ, Ellison AM (1997) The global conservation status of mangroves. Ambio 26(6):328-334

Gallin E, Coppejans E, Beeckman H (1989) The mangrove vegetation of Gazi bay (Kenya). Bull Soc R Bot Belg 122: 197-207

Gilman EL, Ellison J, Jungblut V, Van Lavieren H and others (2006) Adapting to Pacific Island mangrove responses to sea level rise and climate change. Clim Res 32:161-176

Glantz MH (1998) A La niña summit: a review of the causes and consequences of cold events. Executive summary of the workshop held 15-17 July 1998 in Boulder, Colorado. Environmental and Societal Impacts Group, NCAR, Boulder, CO

Hemminga MA, Slim FJ, Kazungu J, Ganssen GM, Nieuwenhuize J, Kruyt NM (1994) Carbon outwelling from a mangrove forest with adjacent seagrass beds and coral reefs (Gazi Bay, Kenya). Mar Ecol Prog Ser 106:291-301

IPCC (Intergovernmental Panel on Climate Change) (2001) Climate change 2001: the scientific basis. Contribution of Working Group I to the Third Assessment Report of the 
Intergovernmental Panel on Climate Change. Houghton JT, Ding Y, Griggs DJ, Noguer M and others (eds). Cambridge University Press, Cambridge

Kahmen H, Faig W (1988) Surveying. De Gruyter, Berlin

Kairo JG (1995) Community participatory forestry for rehabilitation of deforested mangrove areas of Gazi Bay (Kenya). A first approach. Final technical report, Department of Botany, University of Nairobi, Nairobi

Kairo JG (2001) Ecology and restoration of mangrove systems in Kenya. PhD dissertation, Vrije Universiteit Brussel, Brussels

Kairo JG, Dahdouh-Guebas F, Gwada PO, Ochieng C, Koedam N (2002) Regeneration status of mangrove forests in Mida Creek, Kenya: a compromised or secured future? Ambio 31:562-568

Kent M, Coker P (1992) Vegetation description and analysis. A practical approach. John Wiley \& Sons, Chichester

Kenya Ports Authority (2002) Tide tables and port information for Kenya Ports and Tanzania Harbours. Kenya Ports Authority, Mombasa

Krauss KW, Allen JA (2003) Factors influencing the regeneration of the mangrove Bruguiera gymnorrhiza (L.) Lamk. on a tropical Pacific island. For Ecol Manag 176:49-60

Krauss KW, Doyle TW, Twilley RR, Smith TJ, Whelan KRT, Sullivan JK (2005) Woody debris in the mangrove forests of South Florida. Biotropica 37(1):9-15

La Rue CD, Muzik TJ (1951) Does the mangrove really plant its seedlings? Science 114:661-662

Lee MAB (1988) Food preferences and behaviour of the land crab Cardisoma carnifex. Micronesica 21:274-279

Macnae W (1968) A general account of the fauna and flora of mangrove swamps and forests in the Indo-West-Pacific region. Adv Mar Biol 6:73-270

Matthijs S, Tack J, Van Speybroeck D, Koedam N (1999) Mangrove species zonation and soil redox state, sulphide concentration and salinity in Gazi Bay (Kenya), a preliminary study. Mangroves Salt Marshes 3:243-249

Mazda Y, Wolanski E, King B, Sase A, Ohtsuka D, Magi M (1997) Drag force due to vegetation in mangrove swamps. Mangroves Salt Marshes 1:193-199

McCoy J, Johnston K (2002) Using ArcGIS: 3D Analyst. ESRI, Redlands, CA

McKee KL (1993) Soil physiochemical patterns and mangrove species distribution-reciprocal effects? J Ecol 81: $477-487$

McMillan C (1971) Environmental factors affecting seedling establisment of the black mangrove on the central Texas coast. Ecology 52(5):927-930

Nicholls RJ, Hoozemans FMJ, Marchand M (1999) Increasing flood risk and wetland losses due to global sea-level rise: regional and global analyses. Global Environ Change 9: S69-S87

Ochieng CA, Erftemeijer PLA (2002) Phenology, litterfall and

Editorial responsibility: Victor de Jonge,

Hull, UK nutrient resorption in Avicennia marina (Forssk.) Vierh in Gazi Bay, Kenya. Trees 16:167-171

Othman MA (1994) Value of mangroves in coastal protection. Hydrobiologia 285:277-282

Palihawadene NS, Pinto L (1989) Survival of Rhizophora mucronata Lam. and Ceriops tagal (Perr.) C.B. Rob. under different environmental conditions. Sri Lanka For 19(1/2): 31-39

Phuoc VLH, Massel SR (2006) Experiments on wave motion and suspended sediment concentration at Nang Hai, Can Gio mangrove forest, Southern Vietnam. Oceanology 48(1): $23-40$

Rabinowitz D (1978a) Dispersal properties of mangrove propagules. Biotropica 10(1):47-57

Rabinowitz D (1978b) Early growth of mangrove seedlings in Panamá, and an hypothesis concerning the relationship of dispersal and zonation. J Biogeogr 5:113-133

Raper J (1990) Three dimensional applications in Geographical Information Systems. Taylor \& Francis, London

Santos MCFV, Zieman JC, Cohen RRH (1997) Interpreting the upper mid-littoral zonation patterns of mangroves in Maranhão (Brazil) in response to microtopography and hydrology. In: Kjerfve B, de Lacerda LD, Diop EHS (eds) Mangrove Ecosystem Studies in Latin America and Africa. UNESCO, Paris, p 127-144

Slim FJ, Hemminga MA, Cocheret de la Morinière E, van der Velde G (1996) Tidal exchange of macrolitter between a mangrove forest and adjacent seagrass beds (Gazi Bay, Kenya). Neth J Aquat Ecol 30(2-3):119-128

Smith TJ III (1987) Seed predation in relation to tree dominance and distribution in mangrove forests. Ecology 68(2): 266-273

ter Braak CJF, Smilauer P (2002) CANOCO reference manual and CanoDraw for Windows user's guide: software for canonical community ordination (version 4.5.). Biometris, Wageningen

Tomlinson PB (1986) The botany of mangroves. Cambridge University Press, Cambridge

Van Speybroeck D (1992) Regeneration strategy of mangroves along the Kenya coast: a first approach. Hydrobiologia 247: 243-251

Walter H, Steiner M (1936) Die Ökologie der Ost-Afrikanischen Mangroven. Z Bot 30:65-193

Wium-Andersen S (1981) Seasonal growth of mangrove trees in southern Thailand. III. Phenology of Rhizophora mucronata Lamk. and Scyphiphora hydrophyllacea Gaertn. Aquat Bot 10: 371-376

Wium-Andersen S, Christensen B (1978) Seasonal growth of mangrove trees in southern Thailand. II. Phenology of Bruguiera cylindrica, Ceriops tagal, Lumnitzera littorea and Avicennia marina. Aquat Bot 5: 383-390

Woodroffe CD (1990) The impact of sea-level rise on mangrove shorelines. Prog Phys Geogr 14(4):483-520

Submitted: February 17, 2007; Accepted: September 1, 2007 Proofs received from author(s): March 7, 2008 